\title{
Implementation of Simple Additive Weighting in Providing Micro Business Loans at Bank Mandiri Pematangsiantar
}

\author{
Sahat Sonang S. ${ }^{1)^{*}}$, Erwin Sirait ${ }^{2)}$ \\ ${ }^{1) 2}$ Computer Engineering Politeknik Bisnis Indonesia, Pematangsiantar \\ 1) sahatsonangstg@gmail.com
}

\begin{abstract}
Banks are institutions and institutions that are organizations and institutions in Indonesia and have an important role in the sustainability of the Indonesian economy. Bank Mandiri is one of the banks that provides micro business credit facilities to the business world. The higher the public's interest in getting micro business credit, the banks need software to help determine who is entitled to credit. In order to produce a proper feasibility analysis, a method of decision-making in overcoming these problems is needed so that determining who is entitled to receive credit is not too long and efficient in reducing credit risk. Problems arise in the decision-making process for granting microbusiness loans, namely the inaccuracy of micro-business credit recipients. The above problems can be resolved by building a Decision Support System which can assist decision makers in assessing and selecting micro business loans using variables: Income, Collateral, Loan Limit, Installments, Length of Business, Number of Dependents. The system built by applying the Simple Additive Weighting method is known as the method of adding weight. The Simple Additive Weighting method requires a decision matrix normalization process to a scale that can be compared with all available alternative ratings. This will be a reference in ranking and consider the advantages and disadvantages of applying for a credit loan in order to find the desired candidate. From the test results using 10 data samples, it was obtained that the first rank was received credit on behalf of A5 with a value of 9.33, and the last rank was on behalf of A6 with a value of 6.4. and very helpful in solving problems faced by Bank Mandiri Pematangsiantar.
\end{abstract}

Keywords: Decision Support System, Simple Additive Weighting, Credit

\section{INTRODUCTION}

The Indonesian economy is divided into 3 (three) groups of business entities, namely: State-Owned Enterprises (BUMN), Cooperatives, and Private-Owned Enterprises (BUMS). Of the three national economic groups, the government hopes to develop into mutually supportive and integrated components in the national economic system. Problems that are often faced in the business world are lack of capital, partnerships and start-ups. By relying on your own capital, it will be difficult to get a higher income and will grow for a long time (N, Zuraidah, and Sartika 2019)

Banks are institutions and institutions that are organizations and institutions in Indonesia and have an important role in the sustainability of the Indonesian economy. Bank customers or debtors are the top priority in the banking world because they are the fuel for financing in a bank.(Yuliana 2014)(Turuis et al. 2017)

Bank Mandiri is one of the banks that provides micro business credit facilities to the business world. With the increasing interest of the community in obtaining micro business credit, banks experience difficulties in processing and analyzing the feasibility of providing micro business credit by considering several criteria that must be met and this takes a long time which can result in large losses. In overcoming this problem, a method is needed that can assist decision makers in determining who is entitled to receive micro business credit.

The development of technology and science in today's digital era is very significant, especially in the field of computer technology. Computer technology greatly influences human life as well as in terms of data analysis and decision making.(Sonang, Purba, and Siregar 2020) Decision making that is supported by computer technology using certain techniques makes the decision making process more efficient, effective, measurable and objective. Many techniques can be used in decision making, one of which is the Simple Additive Weighting (SAW) method. This method can solve the problem of selecting alternatives in a structured manner by involving multi criteria.

The Simple Additive Weighting (SAW) method is known as the method of adding weight. The basic concept of the SAW method is to find the weighted sum of the performance ratings for each alternative on all attributes. (Fauzan,

* Corresponding author

This is an Creative Commons License This work is licensed under a Creative

Commons Attribution-NoDerivatives 4.0 International License. 
Indrasary, and Muthia 2018)(Ismanto and Effendi 2017) The SAW method requires a decision matrix normalization process $(\mathrm{X})$ to a scale that can be compared with all available alternative ratings. This will be a reference in ranking and take into account the advantages and disadvantages of applying for a credit loan, so that you get the best candidate you want..

\section{Decision Support System (DSS)}

\section{LITERATURE REVIEW}

Interactive computer-based systems to assist decision making by utilizing data and models in solving semistructured and unstructured problems.(Purbal and Sihotang 2019)(Puspa 2019)(Prayogo, Muflikhah, and Wijoyo 2018) Decision Support System is known as research and management science decision-making operations, the difference is that if the first to solve a problem must be manually calculated iterations to find the minimum, maximum, or optimal value, nowadays, the computer can solve the same problem in time. relatively short. (Setiawan 2017)(Resti 2017)

The criteria or characteristics of a Decision Support System are:

1. Many choices or alternatives

2. There are conditions

3. Follow a pattern or model of behavior, whether structured or unstructured

4. Many inputs or variables

5. There are risk factors

6. It takes speed, accuracy, and accuracy. (Windarto 2017)(Riyanto and Haryanti 2017)

\section{Simple Additive Weighting (SAW)}

SAW is one of the methods used in problem solving. Known as the weighted addition method. The basic concept of the SAW method is to find the weighted sum of the performance ratings for each alternative of all attributes. The SAW method requires a decision matrix normalization process $(\mathrm{x})$ to a scale that can be compared with all available alternative ratings. (Hardita, Utami, and Luthfi 2019)(Rochmawati and Marisa 2018)(Putra, Aryanti, and Hartati 2018)

The stages of the Simple Additive Weighting method, namely:

1. Determine the variables used as a reference in decision making, namely $\mathrm{Ci}$

2. Give the weighted value for each variable as $\mathrm{W}$

3. Give the rating value of the suitability of each alternative on each variable

4. Make a decision matrix based on the variable $(\mathrm{Ci})$, then form a normalized matrix based on an equation that is adjusted to the type of attribute so that a normalized matrix $\mathrm{R}$ is obtained.

The formula used to carry out normalization:

$$
\mathrm{R}_{\mathrm{ij}}=\left\{\begin{array}{l}
\frac{\frac{1}{i j}_{i j}}{\operatorname{Max} x_{i j}} \text { jika } j \text { adalah atribut keuntungan (benefit) } \\
\frac{\operatorname{Min} x_{i j}}{x_{i j}} \text { jika } j \text { adalah atribut keuntungan }(\text { cost }) X_{i j}
\end{array}\right\}
$$

Information:

$\mathrm{Rij}=$ Normalized performance rating of the Ai alternatives on the attribute $\mathrm{Cj}: i=1,2, \ldots, m$ and $j=1,2, \ldots, n$

Max Xij = The greatest value of each criterion $\mathrm{i}$

Min Xij $=$ The smallest value of each criterion $\mathrm{i}$

$\mathrm{Xij}=$ The attribute value that each criterion has

Benefit = If the greatest value is best

Cost $=$ If the smallest value is best 
The preference value for each alternative (Vi) is given the following formula:

$$
V_{I}=\sum_{J=1}^{n} w_{J} r_{i j}
$$

Information :

$\mathrm{Vi}=$ Ranking for each alternative

$\mathrm{Wj} \quad=$ Rank weight value (from each alternative)

$\mathrm{Rij}=$ The performance rating value is normalized

Nilai $\mathrm{Vi}=$ the larger one indicates that the alternative Ai is preferred. (Setiadi, Yunita, and Ningsih 2018)(Frieyadie 2016)(Sri and Tamando Sihotang 2019)

\section{Research completion steps}

\section{METHOD}

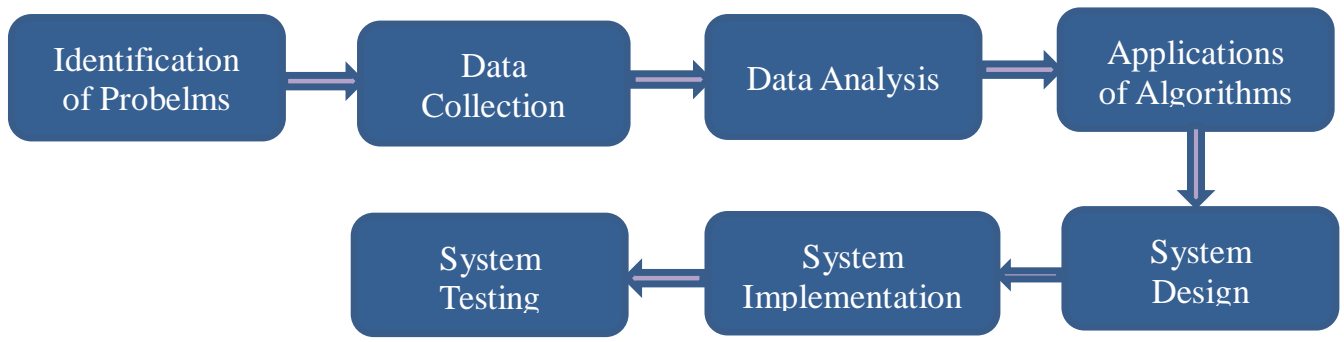

Figure 1. Framework Research

The following is the use case diagram of the Decision System

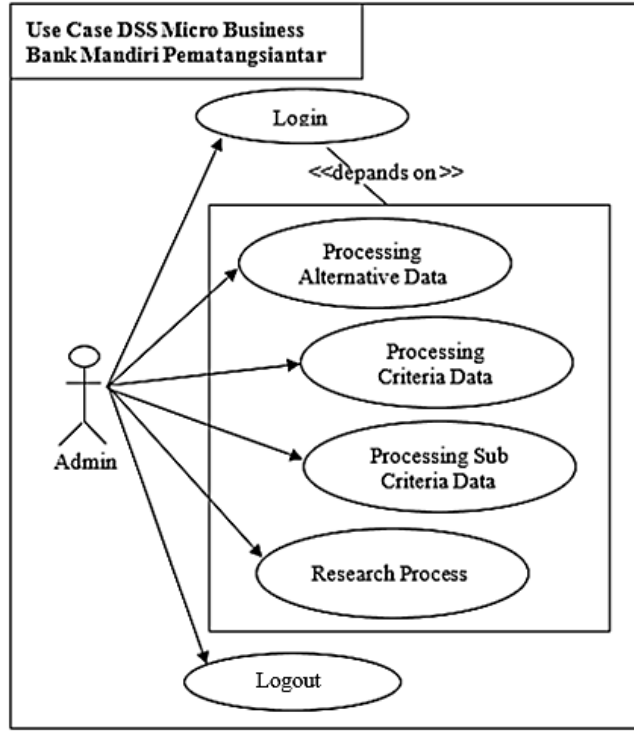

Figure 2. Use Case Diagram

RESULT

\section{Determine The Weight of Each Variabel}


The variables used in determining which debtors are entitled to receive credit loans include 6 criteria, namely: Income, Collateral, Loan Limit, Installments, Length of Business, The Numbes of Dependents.

Table 1

List Variabel

\begin{tabular}{clcc}
\hline \hline Variabels Code & \multicolumn{1}{c}{ Variabels } & Variabels Weigths & Variabels Type \\
\hline C1 & Income & $20 \%$ & Benefit \\
C2 & Collateral & $20 \%$ & Benefit \\
C3 & Loan Limit & $20 \%$ & Benefit \\
C4 & Installments & $20 \%$ & Benefit \\
C5 & Length of Business & $10 \%$ & Benefit \\
C6 & The Numbers of Dependents & $10 \%$ & Cost \\
\hline
\end{tabular}

The value of the Income sub criterion $(\mathrm{C} 1)$

Table 2

Weigthing Income $(\mathrm{C} 1)$

\begin{tabular}{ccc}
\hline \hline Values Range & Weigthing & Values \\
\hline < Rp. 2.000 .000 & Very Low & 1 \\
Rp. $2.000 .000-<$ Rp. 4.000 .000 & Low & 2 \\
Rp. $4.000 .000-<$ Rp. 6.000 .000 & Enough & 3 \\
Rp. $6.000 .000-<$ Rp. 8.000 .000 & High & 4 \\
$>$ Rp.8.000.000 & Very High & 5 \\
\hline
\end{tabular}

The value of the Collateral sub criterion $(\mathrm{C} 2)$

Table 3

Weighting Collateral (C2)

\begin{tabular}{ccc}
\hline Values Range & Weigthing & Values \\
\hline <.Rp. 10.000 .000 & Very Low & 1 \\
Rp. $10.000 .000-<$ Rp. 20.000 .000 & Low & 2 \\
Rp. $20.000 .000-<$ Rp. 30.000 .000 & Enough & 3 \\
Rp. $30.000 .000-<$ Rp. 40.000 .000 & High & 4 \\
> Rp. 40.000 .000 & Very High & 5 \\
\hline
\end{tabular}

The value of the Loan Limit sub criterion (C3)

Table 4

Weights Loan Limit (C3)

\begin{tabular}{ccc}
\hline \hline Values Range & Weigthing & Values \\
\hline <.Rp. 5.000.000 & Very Low & 1 \\
Rp. 5.000.000 - < Rp. 15.000 .000 & Low & 2 \\
Rp. $15.000 .000-<$ Rp. 25.000 .000 & Enough & 3 \\
Rp. 25.000.000 - < Rp. 35.000.000 & High & 4 \\
> Rp. 35.000.000 & Very High & 5 \\
\hline
\end{tabular}

The value of the Installments sub criterion $(\mathrm{C} 4)$

Table 5

Weights Installments (C4) 


\begin{tabular}{ccc}
\hline \hline Values Range & Weigthing & Values \\
\hline 12 Month & Very Low & 1 \\
18 Month & Low & 2 \\
24 Month & Enough & 3 \\
30 Month & High & 4 \\
36 Month & Very High & 5 \\
\hline
\end{tabular}

The value of the Length of Business sub criterion (C5)

Table 6

Weight Length of Business (C5)

\begin{tabular}{ccc}
\hline \hline Values Range & Weigthing & Values \\
\hline$<2$ Year & Very Low & 1 \\
2 s/d 3 Year & Low & 2 \\
3 s/d 4 Year & Enough & 3 \\
4 s/d 5 Year & High & 4 \\
$>$ 5 Year & Very High & 5 \\
\hline
\end{tabular}

The value of the Numbers of Dependents sub criterion (C6)

Table 7

Weight Numbers of Dependents (C6)

\begin{tabular}{ccc}
\hline \hline Values Range & Weigthing & Values \\
\hline 0 & Very Low & 1 \\
1 Person & Low & 2 \\
2 Person & Enough & 3 \\
3 Person & High & 4 \\
$>$ 4 Person & Very High & 5 \\
\hline
\end{tabular}

\section{Calculation Using the SAW Method}

1. Alternative Data

Table 8

Alternative Data

\begin{tabular}{|c|c|c|c|c|c|c|c|}
\hline No & Jame & C1 & $\mathrm{C2}$ & $\mathbf{C 3}$ & C4 & C5 & C6 \\
\hline 3. & A & & & $00-\mathrm{R}_{1}$ & & $2-3$ & on \\
\hline 5 . & A5 & p 8.000 .000 & & & & $>5$ year & 2 person \\
\hline 6. & A6 & & & & & $<2$ year & 0 \\
\hline 7. & A7 & & & & & $3-4$ year & 3 person \\
\hline 8. & A8 & Rp 4.000 .000 - Rp 6.000 .000 & $>\mathrm{Rp} 40.000 .000$ & Rp 15.000.000 - Rp 25.000.000 & $36 \mathrm{mc}$ & $>5$ year & 2 person \\
\hline
\end{tabular}

2. Alternative Match Ratings

Table 9

Alternative Match Ratings 


\begin{tabular}{ccccccc}
\hline \hline \multirow{2}{*}{ Alternative } & C1 & C2 & C3 & C4 & C5 & C6 \\
\hline A1 & 3 & 3 & 3 & 5 & 5 & 3 \\
A2 & 2 & 5 & 3 & 5 & 5 & 3 \\
A3 & 4 & 5 & 3 & 5 & 2 & 3 \\
A4 & 2 & 4 & 2 & 5 & 5 & 3 \\
A5 & 4 & 5 & 4 & 5 & 5 & 3 \\
A6 & 2 & 5 & 2 & 3 & 1 & 1 \\
A7 & 3 & 5 & 4 & 5 & 3 & 4 \\
A8 & 3 & 5 & 3 & 5 & 5 & 3 \\
A9 & 3 & 5 & 4 & 5 & 3 & 3 \\
A10 & 2 & 5 & 2 & 3 & 4 & 2 \\
\hline
\end{tabular}

3. Decision Matrix $X$

$$
X=\left\{\begin{array}{llllll}
3 & 3 & 3 & 5 & 5 & 3 \\
2 & 5 & 3 & 5 & 5 & 3 \\
4 & 5 & 3 & 5 & 2 & 3 \\
2 & 4 & 2 & 5 & 5 & 3 \\
4 & 5 & 4 & 5 & 5 & 3 \\
2 & 5 & 2 & 3 & 1 & 1 \\
3 & 5 & 4 & 5 & 3 & 4 \\
3 & 5 & 3 & 5 & 5 & 3 \\
3 & 5 & 4 & 5 & 3 & 3 \\
2 & 5 & 2 & 3 & 4 & 2
\end{array}\right\}
$$

4. X matrix normalization to calculate the value of each criterion based on predetermined criteria

a. $\mathbf{A 1}$
$r 11=\frac{X 11}{\operatorname{Max} 11}$
$r 11=\frac{3}{4}=0.75$
$r 12=\frac{X 12}{\operatorname{Max} 12}$
$r 12=\frac{3}{5}=0.60$
$r 13=\frac{X 13}{\operatorname{Max} 13}$
$r 13=\frac{3}{4}=0.75$
$r 14=\frac{X 14}{\operatorname{Max} 14}$
$r 14=\frac{5}{5}=1.00$
$r 15=\frac{X 15}{\operatorname{Max} 15}$
$r 15=\frac{5}{5}=1.00$
$r 16=\frac{M i n 16}{X 16}$
$r 16=\frac{1}{3}=0.33$

b. $\mathbf{A 2}$
$r 21=\frac{X 21}{\operatorname{Max} 21}$
$r 21=\frac{2}{4}=0.50$
$r 22=\frac{X 21}{\operatorname{Max} 21}$
$r 22=\frac{5}{5}=1.00$
$r 23=\frac{X 23}{\operatorname{Max} 23}$
$r 23=\frac{3}{4}=0.75$
$r 24=\frac{X 24}{M a x 24}$
$r 25=\frac{X 25}{M a \times 25}$
$r 24=\frac{5}{5}=1.00$
$r 25=\frac{5}{5}=1.00$ 


$$
r 26=\frac{\operatorname{Min} 26}{X 26} \quad r 36=\frac{1}{3}=0.33
$$

From the results of the above calculations, the matrix is normalized

Table 10

Matrix is Normalized

\begin{tabular}{ccccccc}
\hline \hline Name & C1 & C2 & C3 & C4 & C5 & C6 \\
\hline A1 & 0.75 & 0.60 & 0.75 & 1.00 & 1.00 & 0.33 \\
A2 & 0.50 & 1.00 & 0.75 & 1.00 & 1.00 & 0.33 \\
A3 & 1.00 & 1.00 & 0.75 & 1.00 & 0.40 & 0.33 \\
A4 & 0.50 & 0.80 & 0.50 & 1.00 & 1.00 & 0.33 \\
A5 & 1.00 & 1.00 & 1.00 & 1.00 & 1.00 & 0.33 \\
A6 & 0.50 & 1.00 & 0.50 & 0.60 & 0.20 & 1.00 \\
A7 & 0.75 & 1.00 & 1.00 & 1.00 & 0.60 & 0.25 \\
A8 & 0.75 & 1.00 & 0.75 & 1.00 & 1.00 & 0.33 \\
A9 & 0.75 & 1.00 & 1.00 & 1.00 & 0.60 & 0.33 \\
A10 & 0.50 & 1.00 & 0.50 & 0.60 & 0.80 & 0.50 \\
\hline
\end{tabular}

5. Multiply the matrix $\mathrm{W} X \mathrm{R}$ and add the product to get the best alternative

$\mathrm{V} 1=(2.0,75)+(2.0,60)+(2.0,75)+(2.1)+(1.1)+(1.0,33)=7,53$

$\mathrm{V} 2=(2.0,50)+(2.1)+(2.0,75)+(2.1)+(1.1)+(1.0,33)=7,83$

Table 11

Alternative Rankings

\begin{tabular}{ccc}
\hline No & Name & Reference Values \\
\hline 1. & A5 & 9,33 \\
2. & A9 & 8.43 \\
3. & A7 & 8.35 \\
4. & A8 & 8.33 \\
5. & A3 & 8,23 \\
6. & A2 & 7.83 \\
7. & A1 & 7.53 \\
8. & A4 & 6.93 \\
9. & A10 & 6.50 \\
10. & A6 & 6.40 \\
\hline
\end{tabular}

From the above calculations, it can be seen that the first member eligible for credit is A5 with a score of 9.33, second is A9 with a score of 8.43 , third is A7 with a value of 8.35, fourth is A8 with a value of 8.33 , fifth is A3 with a value of 8.23 , sixth is A2 with a value of 7.83, the seventh is A1 with a value of 7.51 , the eighth is A4 with a value of 6.93, the ninth is A10 with a value of 6.50, and the last one is A6 with a value of 6.40. The Chart of Preference Value Sorting can be seen in Figure 3. 


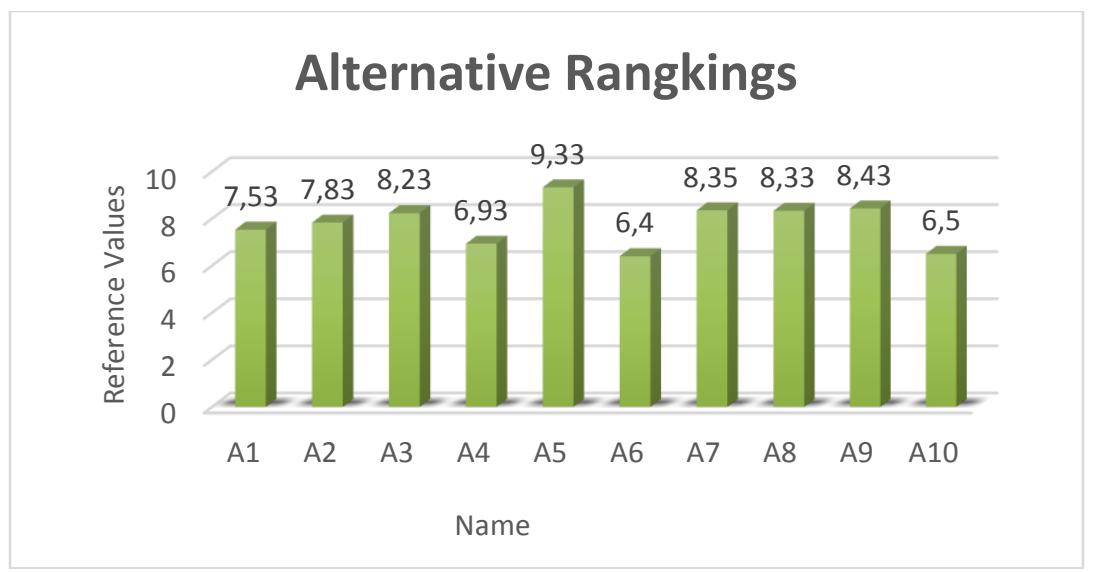

Figure 3. Alternative Rangkings

Test Results with the system that is built

\begin{tabular}{|c|c|c|}
\hline NIK & NAME & VALUES \\
\hline 1107010812930001 & Muhammad & 7.53 \\
\hline 1272020109670001 & Wargini & 7.83 \\
\hline 1272020306700001 & Marwan & 8.23 \\
\hline 1272021204630001 & Usman & 6.93 \\
\hline 1272021406670004 & Suparmen & 9.33 \\
\hline 1272022004920002 & Ari Afriandi Batubara & 6.4 \\
\hline 1272022409710001 & Dendi Junaidi & 8.35 \\
\hline 1272022502700001 & Adek Lubis & 8.33 \\
\hline 1272023112600027 & Ediwirman & 8.43 \\
\hline 1272024111720003 & Hariani & 6.5 \\
\hline
\end{tabular}

Figure 4. Test Results with the system that is built

\section{DISCUSSIONS}

System testing is done either by manual calculation or using a decision support system that is built using a sample of data 10, the same results are obtained, this indicates that the system built is in accordance with the SAW method. Decision support systems built can provide better, timely, and efficient information. This system can help the management of Bank Mandiri Pematangsiantar in solving problems faced in providing micro-business loans.

Table 12

Calculation Analysis

\begin{tabular}{cccc}
\hline \hline Nama & Calculation of Seniors & System Calculation & Evaluastion \\
\hline A1 & 7.53 & 7.53 & Appropriate \\
A2 & 7.83 & 7.83 & Appropriate \\
A3 & 8.23 & 8.23 & Appropriate \\
A4 & 6.93 & 6.93 & Appropriate \\
A5 & 9.33 & 9.33 & Appropriate \\
A6 & 6.4 & 6.4 & Appropriate \\
A7 & 8.35 & 8.35 & Appropriate \\
A8 & 8.33 & 8.33 & Appropriate \\
A9 & 8.43 & 8.43 & Appropriate \\
A10 & 6.5 & 6.5 & Appropriate \\
\hline
\end{tabular}




\section{Journal of Computer Networks, Architecture and High Performance Computing}

Volume 3, Number 1, January 2021

https://doi.org/10.47709/cnahpc.v3i1.948
Submitted : Apr 14, 2021

Accepted : Apr 18, 2021

Published : Apr 21, 2021

\section{CONCLUSION}

The decision support system for providing micro-business loans that has been built using the SAW method can help Bank Mandiri Pematangsiantar in providing recommendations and solutions according to the needs of Bank Mandiri Pematangsiantar. From the test conducted using 10 data samples, the first rank was in the name of A5 with a value of 9.33, the second was in the name of A9 with a value of 8.23, the third was in the name of A7 with a value of 8.35 , fourth was in the name of $\mathrm{A} 8$ with a value of 8.33 , the fifth was in the name of $\mathrm{A} 3$ with a value 8.23 , the sixth is in the name of $\mathrm{A} 2$ with a value of 7.83, the seventh is in the name of $\mathrm{A} 1$ with a value of 7.53 , the eight is in the name of A4 with a value of 6.93, the ninth is in the name of A10 with a value of 6.5, and the tenth is on behalf of A6 with a value of 6.4. The decision support system for creditworthiness with the SAW method can make it easier and very helpful in solving problems faced by Bank Mandiri Pematangsiantar in determining creditworthiness.

\section{REFERENCES}

Fauzan, Reza, Yoenie Indrasary, and Nonik Muthia. 2018. "Sistem Pendukung Keputusan Penerimaan Beasiswa Bidik Misi Di POLIBAN Dengan Metode SAW Berbasis Web." Jurnal Online Informatika 2(2): 79.

Frieyadie, Frieyadie. 2016. "Penerapan Metode Simple Additive Weight (Saw) Dalam Sistem Pendukung Keputusan Promosi Kenaikan Jabatan.” Jurnal Pilar Nusa Mandiri 12(1): 37-45.

Hardita, Veny Cahya, Ema Utami, and Emha Taufiq Luthfi. 2019. "Penerapan Simple Additive Weighting Pada Pemilihan Canvasser Terbaik PT.Eratel Prima.” Jurnal Teknologi Informasi dan Ilmu Komputer 6(5): 567.

Ismanto, Edi, and Noverta Effendi. 2017. "Sistem Pendukung Keputusan Penerimaan Karyawan Dengan Metode Simple Additive Weighting (SAW)." SATIN - Sains dan Teknologi Informasi 3(1): 1.

N, Nelfa, Zuraidah Zuraidah, and Fani Sartika. 2019. "Pengaruh Pemberian Kredit Dan Modal Terhadap Pendapatan Pedagang Kecil.” Jurnal Ilmu Manajemen 9(1): 26.

Prayogo, Hanggar Wahyu Agi, Lailil Muflikhah, and Satrio Hadi Wijoyo. 2018. "Implementasi Metode Simple Additive Weighting ( SAW ) Untuk Penentuan Penerima Zakat." Jurnal Pengembangan Teknologi Informasi dan Ilmu Komputer 2(11): 5877-83.

Purbal, Rosulastri, and Hengki Tamando Sihotang. 2019. "Decision Support Systems Recipient Program Keluarga Harapan (PKH) In Durian Kec.Pantai Labu Kab. Deli Serdang with the Simple Additive Weighting (SAW) Method.” Jurnal Mantik 3(November): 91-98.

Puspa, Maulisa. 2019. "Decision Support System For Supplementary Food Recipients (PMT) By Using The Simple Additive Weighting (SAW) Method." Jurnal Teknik Informatika C.I.T 11(2): 37-44. www.medikom.iocspublisher.org/index.php/JTI.

Putra, Arie Setya, Desi Rahma Aryanti, and Indah Hartati. 2018. "Metode SAW (Simple Additive Weighting) Sebagai Sistem Pendukung Keputusan Guru Berprestasi ( Studi Kasus : SMK Global Surya)." Prosiding Seminar Nasional Darmajaya 1(1): 85-97. https://jurnal.darmajaya.ac.id/index.php/PSND/article/view/1233/763.

Resti, Nalsa Cintya. 2017. "Penerapan Metode Simple Additive Weighting (SAW) Pada Sistem Pendukung Keputusan Pemilihan Lokasi Untuk Cabang Baru Toko Pakan UD. Indo Multi Fish.” Intensif 1(2): 102.

Riyanto, Eko Arif, and Tuty Haryanti. 2017. "Sistem Pendukung Keputusan Pemilihan Teller Pooling Terbaik pada PT. BCA tbk. Dengan metode saw (Simple Additive Weighting)." Jurnal Pilar Nusa Mandiri 13(1): 128-35.

Rochmawati, Sofi Nur, and Fitri Marisa. 2018. "Sistem Rekomendasi Rumah Berbasis Web Menggunakan Metode SAW Pada PT.Inproperty." JOINTECS (Journal of Information Technology and Computer Science) 3(2): 9598.

Setiadi, Ahmad, Yunita Yunita, and Anisa Ratna Ningsih. 2018. "Penerapan Metode Simple Additive Weighting(SAW) Untuk Pemilihan Siswa Terbaik.” Jurnal Sisfokom (Sistem Informasi dan Komputer) 7(2): 104.

Setiawan, Adil. 2017. "Implementasi Metode SAW Dalam Penerimaan Siswa Baru Pada SMA Negeri 16 Medan." Jurasik (Jurnal Riset Sistem Informasi dan Teknik Informatika) 2(1): 96.

Sonang, Sahat, Arifin Tua Purba, and Victor Marudut Mulia Siregar. 2020. "Sistem Pendukung Keputusan Kelayakan Pemberian Pinjaman Kredit Menggunakan Metode Topsis Pada Cum Caritas Hkbp Pematangsiantar.” Jurnal Teknik Informasi dan Komputer (Tekinkom) 3(1): 25.

Sri, Devi, and Hengki Tamando Sihotang. 2019. "Decision Support Systems Assessment of the Best Village in Perbaungan Sub-District with the Simple Additive Weighting (SAW) Method." Jurnal Mantik 3(January): 31- 
38.

Turuis, Tanri F et al. 2017. "Analisis Prosedur Pemberian Kredit Dengan Menggunakan Prinsip-Prinsip Good Corporate Governance Pada Pt. Bank Sulutgo.” Jurnal Berkala Ilmiah Efisiensi 17(01): 113-23.

Windarto, Agus Perdana. 2017. "Penilaian Prestasi Kerja Karyawan PTPN III Pematangsiantar Dengan Metode Simple Additive Weighting (SAW).” Jurasik (Jurnal Riset Sistem Informasi dan Teknik Informatika) 2(1): 84.

Yuliana, Rachma. 2014. "Pengaruh Pemberian Kredit Dan Risiko Kredit Terhadap Keputusan Pemberian Kredit Pada Debitur." 26(1): 85-91. 